\title{
パラ置換ベンジルラジカルの励起状態 およびその分子間相互作用
}

\author{
（1989年 1 月 27 日受理） \\ 德 村 邦 弘* ・伊 藤 道 也
}

\begin{abstract}
室温へキサン中安定には存在し得ないパラ置換ベンジルラジカル $\left(\mathrm{D}_{0}\right)$ の励起状態 $\left(\mathrm{D}_{1}\right)$ の電子ス ペクトル $\left(\mathrm{D}_{1} \rightarrow \mathrm{D}_{0}\right.$ 蛍光, $\mathrm{D}_{n} \leftarrow \mathrm{D}_{1}$ 吸収スペクトル)を, 2 段励起レーザー分光法により測定した。シ アノ,メトキシ, フッ素, 塩素がパラ位に導入されたベンジルの蛍光寿命が比較的長い（>50 ns）こ とから，励起状態ラジカルとアミンやジェンとの分子間相互作用を蛍光消光により検討した。また，こ れらラジカルが室温溶液中蛍光性であることを利用して, パラ置換トルェン三重項 $\left(\mathrm{T}_{1}\right)$ からパラ置 換ベンジルラジカル二重項 $\left(\mathrm{D}_{0}\right)$ への T-D エネルギー移動を明らかにした。
\end{abstract}

\section{1 緒言}

有機光化学反応の光源にレーザーを用いると，定常光照射とは 異なる生成物が得られたり，生成物の割合が変化することが多 い。これは，レーザーによる高密度励起のため，中間体や生成物 がさらに光励起されるためであり，特に中間体の励起状態が重要 な役割を演じていることが示唆されている1。

芳香族遊離基のプロトタイプであるベンジルラジカルおよびそ の誘導体は，多くの有機光化学反応に怙ける中間体として知られ ている。このため, 最も一般的でかつ有用な反応媒体である室温 溶液中に持ける励起状態ベンジルラジカルについての知見を得る 必要がある。最近, 前駆物質のレーザー光分解で生成したベンジ ルラジカル（基底状態）をこのレーザーに同期した第 2 のレー ザーで選択的励起する 2 段励起レーザー分光法により，蛍光過程 と競合する無放射失活過程がいちじるしい温度依存性を示し，室 温溶液中の虽光寿命は $1 \mathrm{~ns}$ 程度と見積られた ${ }^{233}$ 。これに対して 著者らは，多くのパラ置換ヘンシジラジカルが，室温へキサン中 で $50 \mathrm{~ns}$ 以上もの蛍光寿命を示すことを見いたした ${ }^{3 / 4)}$ 。本論文 は, これらパラ置換ベンジルラジカルの励起状態の電子スペクト ル測定, 励起状態緩和過程と反応拈よび三重項一二重項エネルギ 一移動による励起状態の生成などについて述べる。

金沢大学大学院自然科学研究科生命科学専攻, 920 金沢 市宝町 金沢大学薬学部, 920 金沢市宝町

1) J. C. Scaiano, L. J. Johnston, W. G. McGimpsey, D. Weir, Acc. Chem. Res., 21, 22(1988) and References therein.

2) D. Meisel, P. K. Das, G. L. Hug, K. Bhattacharyya, R. W. Fessenden, J. Am. Chem. Soc., 108, 4706 (1986).

3) K. Tokumura, M. Udagawa, T. Ozaki, M. Itoh, Chem. Phys. Lett., 141, 558(1987).

4) K. Tokumura, T. Ozaki, M. Udagawa, M. Itoh, J. Phys. Chem., 93, 161(1989).

\section{2 実験}

2.1 試 薬

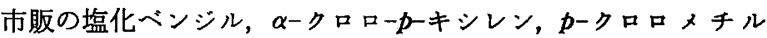
アニソール, 塩化 $p$-フルオロベンジル, 塩化 $p$-クロロベンジル などのハロゲン化ベンジルと, $p$-クロロトルエン, $p$-フルオロト ルェン, $p$-メチルアニソールなどのパラ置換トルエンは, いずれ も減王蒸留により精製して用いた。 $\alpha$-ブロモーp-トルニトリルは エタノールから再結晶した。これらをスペクトル用へキサンに溶 解し, 融解凍結法により脱気した。蛍光の消光剂として用いた 1,4-ジアザビシクロ[2.2.2]オクタン (DABCO)，1４４-シクロへ キサジェン(CHD) は，それぞれ昇華，シリカカラム管を通すこ とにより精製して用いた。

\subsection{2 段励起レーザー分光法}

八ロゲン化ベンジルやハロトルェンの光分解には，エキシマー レーザー (Lambda Physik EMG50E) の $248 \mathrm{~nm}$ パルス (KrF；75 mJ ; 14-ns FWHM) を用いた。この光分解で生成した ベンジルラジカル（基底状態）を選択的に励起するために，エキ シマーレーザー (Lambda Physik EMG 53 MSC) の $308 \mathrm{~nm}$ パ ルス $(\mathrm{XeCl} ; 80 \mathrm{~mJ} ; 13-\mathrm{ns} \mathrm{FWHM})$ を用いた。308 nm では, 前駆物質の吸収が無視できるからである。両バルス間の遅延時間 は，遅延パルス発生機（BNC 7010）により，最小 $100 \mathrm{~ns}$ 刻みで 可変である。過渡吸収やレーザー誘起絈光の測定には，通常のレ ーザーフラッシュ分光装置を用い光電子増倍管 (浜松フォトニク ス R 666，R 928）により検出した。光電子增倍管からの電気信号 は, ストレージスコープ (Iwatsu TS 8123) でディジタル化され て取り込まれ，マイコンによりデータ処理された。

図 $1 \mathrm{~A}$ に 2 段励起過渡吸収の典型的オッシログラムを示す。初 段レーザー励起前のモニター光強度を $I_{0}$ とし，初段レーザー誘 起過渡吸収および 2 段励起過渡吸収のモニター光強度を $I_{1}(t)$, $I_{2}(t)$ とすると，2段励起過渡吸収の吸光度は（1）式で表され る。 


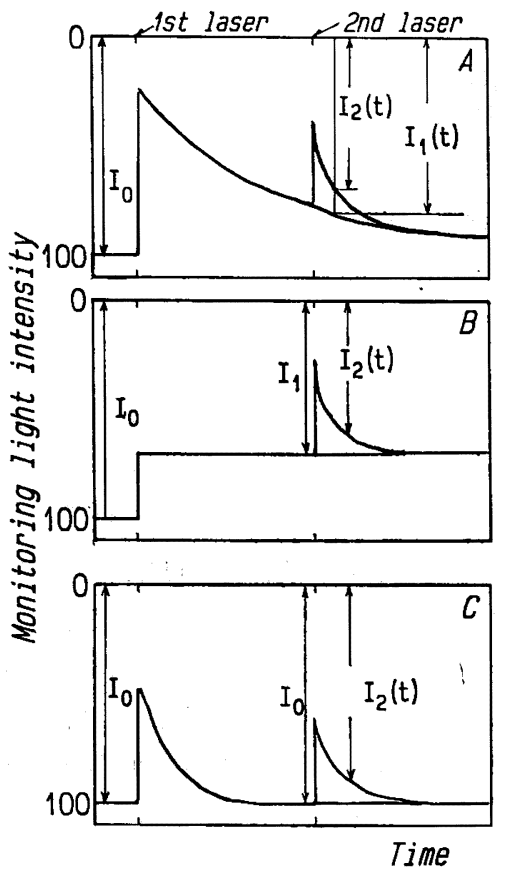

Fig. 1 Typical oscillograms for the two-step laser-induced-absorption

$$
D(t)=\log \left[I_{1}(t) / I_{2}(t)\right]
$$

$I_{1}(t)$ と $I_{2}(t)$ を同時に測定できないので, 初段のみの励起と 2段励起の測定を同一の条件下セットで測定する必要がある。こ の踏, これら二つの測定の初段励起過渡四収が一致するのが目安 である。ただし， 2 段励起後の $I_{1}(t)$ が直線などで近似できる 時，2段励起の測定の及行ら場合がある。

Bのオッシログラムのように, $I_{1}$ が一定の時, $D(t)$ は (2) 式のように差スペクトルとして表される。

$$
D(t)=\log \left[I_{1} / I_{2}(t)\right]=\log \left[I_{0} / I_{2}(t)\right]-\log \left(I_{0} / I_{1}\right)
$$

この状沉は，初段レーザー励起により安定生成物ができる場合は もちろん, 初段朸起過渡吸収の減衰が 2 段励起過渡吸收の減哀に くらべて無視できる場合である。一方，Cのオッシログラムのよ 5 K，2段励起以前飞初段励起過渡吸收が減衰してしま5場合は 通常の 1 段朸起過渡吸收々同等飞扱宇， $I_{0}$ を用いて (3) 式で表 される。

$$
D(t)=\log \left[I_{0} / I_{2}(t)\right]
$$

初段励起過渡四収が観測波長にない場合む同様に（3）式で表せ る。しかしながらこのよらなシグナルが観測されることは少な く，実際に観測されるすのは，むしろCのオッシログラムであ る。すなわち，初段レーザーの 1 光子吸収で諗起される過渡吸収 が現われなくても，初段レーザーパルスの段階的 2 光子吸収で 2 段励起過渡吸収が㛬起されるので，初段励起拉よび 2 段励起過渡 吸収の減衰寿命が同一のオッシログラムとなる (図 3 参照)。

このよらな 2 段励起過渡吸収の検出には，種々の条件が満され ねばならない。すなわち，前駆物質のレーザー光分解で高湄度の 中間体を生成させ，その中間体の分子吸光係数の大きい吸収帯を 2 段目のレーザーパルスで励起した場合に分子多光係数の大きい
2 段彷起過渡吸收带が現われるのが理想である。また 2 段目のレ ーザーパルスが前駆物質を励起しないのが望ましい。装置的に は, 二つのレーザーがともに高出力であり，できるだけレーザー 散乱光などの発光を検知しない検出系であることが大切である。 さもないと，せっかくの 2 段励起吸収が発光により打ち消されて しまらからである。著者らは二つの約 $80 \mathrm{~mJ}$ のエキシマーレー ザーパルスを用い，パルス化により光強度を数十倍に高めた Xe アーク光をモニター光として 2 段励起吸収を測定した。また，試 料セルとモノクロメーターとの間にアイリスを入れることによ り，発光のカットを計った。

\section{3 結果および考察}

\section{1 パラ置換ベンジルラジカルの電子スペクトル}

$77 \mathrm{~K}$ 剛性溶媒中のトルェンの光分解により生成するベンジル ラジカルは安定に捕捉され，濃度計 (densitometer) で測定され た吸収スペクトル5)や蛍光励起スペクトル6゙年が報告されている。 これに対し流動性溶媒中のベンジルラジカルは拡散でき，カップ リング反応により消失してビベンジルなどを生成する。Claríge と Fischer は変調分光法 (Optical Modulation Spectroscopy) を用いて，室温シクロヘキサン中の種々の置換シシベンジルケトン の光分解により生成する置換ベンジルラジカルの吸収スペクトル を測定した ${ }^{10)}$ この方法では，ラジカル濃度が低くてもシグナル 強度を增幅できるしかしながら本研究の目的は最低版起二重項 状態 $\left(\mathrm{D}_{1}\right)$ の吸収スペクトルの測定であるので, 高濃度の基底状 態ラジカルを生成させて高密度励起することが不可欠である。こ の点に拈いて，レーザーや加速電子のパルス励起により一挙洫高 濃度のラジカルを生成させてその吸収スペクトルを測定する過渡 吸収分光法が適している。ところで，ハロダン化ベンジルの C-X 結合の方が，トルエンのメチル基の $\mathrm{C}-\mathrm{H}$ 結合にくらべてホモリ ティック開裂しやすい。そこで本研究では，室温へキサン中の種 タのパラ置換ハロダン化ベンジルの $\mathrm{KrF}$ レーザー光分解化より 生成するパラ置换ベンジルの $\mathrm{D}_{n} \leftarrow \mathrm{D}_{0}$ 吸収スペクトルの測定か ら始めた。

3.1 .1 基底状態の $\mathrm{D}_{n} \leftarrow \mathrm{D}_{0}$ 吸収スベクトル：pークロロメチル アニソール (CMA) の $\mathrm{KrF}$ レーザー光分解を例にとって述べ

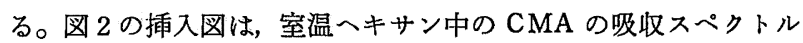
である。CMA の $248 \mathrm{~nm}$ パルス励起の $1.4 \mu \mathrm{s}$ 後得られた過 渡吸収スペクトルを図 2 亿示す。CMA の $\mathrm{S}_{n} \leftarrow \mathrm{S}_{0}$ 吸収のブリー チングによる補正をしていないが，285 nm にピークを有する強 い吸收帯が見られる。また $300 \mathrm{~nm}$ から $330 \mathrm{~nm}$ にかけて比較的 強い吸収帯があり，その長波長側飞見られる弱い吸収带は500 $\mathrm{nm}$ 付近まで続いている。これらの吸収帯は二次の減衰を示し,

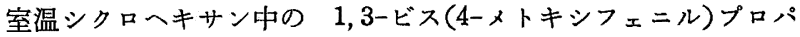

5) G. Porter, E. Strachan, Spectrochim. Acta, 12, 299 (1958).

6) G. Porter, M. I. Savadatti, ibid., 22, 803(1966).

7) D. M. Friedrich, A. C. Albrecht, Chem. Phys., 6, 366 (1974).

8) T. Okamura, I. Tanaka, J. Phys. Chem., 79, 2728 (1975).

9) H. Hiratsuka, T. Okamura, I. Tanaka, Y. Tanizaki, ibid., 84, 285(1980).

10) R. F.C.Claridge, H. Fischer, ibid., 87, 1960(1983). 


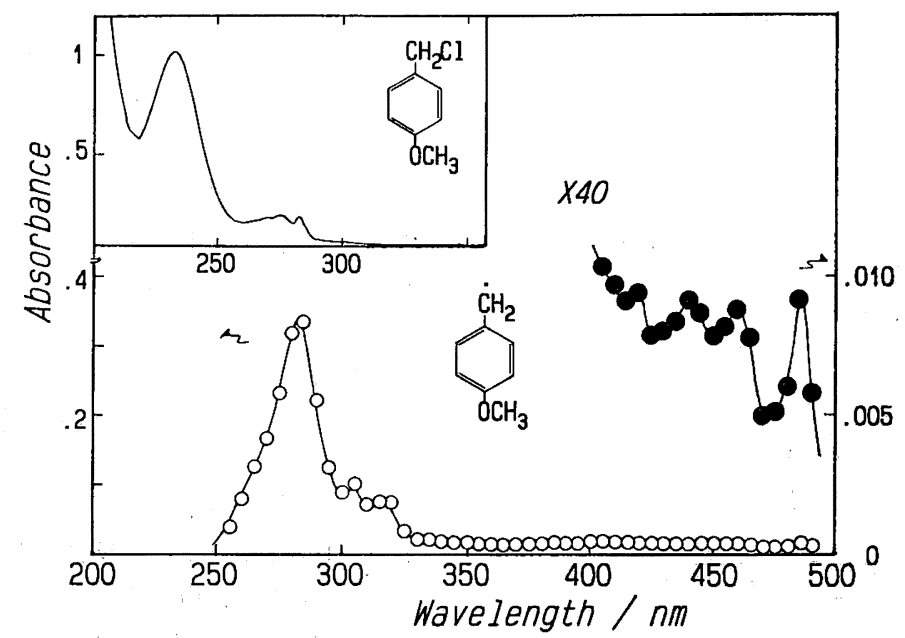

Fig. 2 Transient absorption spectrum observed at $1.4 \mu \mathrm{s}$ delay from $248 \mathrm{~nm}$ pulse excitation of $p$-(chloromethyl)anisole (0. $31 \mathrm{mM}$ ) in hexane at room temperature

Visible spectrum is enlarged $(\times 40)$

Inset shows the ordinary absorption spectrum of the anisole

ン-2-オンの $\mathrm{n} \pi$ * 吸収帯励起の Optical Modulation Spectroscopy で得られた $p$ ーメトキシベンジルラジカルの紫外可視スペクト ル $\left(\lambda_{0,0}=283,321,485 \mathrm{~nm}\right)^{10)}$ によく似ている。それゆ光, CMA のレーザー光分解により得られた二次減衰を示す過渡吸収 スペクトルは, $p$-メトキシベンジルラジカルの $\mathrm{D}_{n} \leftarrow \mathrm{D}_{0}$ 吸収スペ クトルと同定できる。その他のパラ置換ハロゲン化ベンジル $(\alpha-$ クロロ-p-キシレン, 塩化 $p$-フルオロベンジル, $\alpha-フ ゙ ロ モ-p-ト$

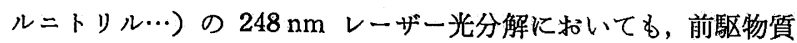
(ハロゲン化ベンジル) の $\mathrm{T}_{n} \leftarrow \mathrm{T}_{1}$ 吸収スペクトルはほとんど認 められず対応するパラ置換ベンジルラジカルの $\mathrm{D}_{n} \leftarrow \mathrm{D}_{0}$ 吸収ス ペクトルが得られた。つぎに, $\mathrm{D}_{n} \leftarrow \mathrm{D}_{0}$ 吸収スペクトルの各吸収 帯の州属について述べる。

$\mathrm{C}_{2 \mathrm{v}}$ の対称性を有し, 偶交互炭化水素ラジカルである基底状態 ベンジルラジカル $\left(1 \mathrm{~B}_{2}\right)$ では最低励起状態 $\left(\mathrm{D}_{1}\right)$ と $\mathrm{D}_{2}$ のエネ ルギー準位が近接していて, $\mathrm{D}_{1}$ と $\mathrm{D}_{2}$ の帰属については論 争1112) の後 $\mathrm{D}_{1}$ が $1 \mathrm{~A}_{2}$ で $\mathrm{D}_{2}$ が $2 \mathrm{~B}_{2}$ と帰属された。 $1 \mathrm{~A}_{2} \rightarrow 1 \mathrm{~B}_{2}$ および $2 \mathrm{~B}_{2} \rightarrow 1 \mathrm{~B}_{2}$ 遷移の振動子強度は〜 0.001 と小さく, 可視部 の弱い吸收スペクトルに対応している。一方，近紫外の比較的強 い $\mathrm{D}_{n} \leftarrow \mathrm{D}_{0}$ 吸收带は, $2 \mathrm{~A}_{2} \rightarrow 1 \mathrm{~B}_{2}$ 㧊よび $4 \mathrm{~B}_{2} \rightarrow 1 \mathrm{~B}_{2}$ 遷移に帰属さ れている(10)。なお， $p$-メチルベンジルラジカルを初め対称性の 低下した種々の置換ベンジルラジカルについても類似のスペクト ルが測定され，便宜上 $\mathrm{C}_{2 \mathrm{v}}$ 対称性に基づく同様の帰属が行われ ている。

$3.1 .2 \mathrm{D}_{1} \rightarrow \mathrm{D}_{0}$ 蛍光スペクトル : 芳香族ラジカルであるベン ジルラジカルは, アルキルラジカルのような水素引き抜き能力に 乏しいので, ヘキサン中でもラジカル同士のカップリング反応に より徐々に消失していく。したがって，前節で述べたように八口 ゲン化ベンジルの $248 \mathrm{~nm}$ レーザー光分解によりラジカル（基底 状態）を生成させた後, その過渡吸収励起により $\mathrm{D}_{1} \rightarrow \mathrm{D}_{0}$ 営光を

11) D. M. Friedrich, A.C. Albrecht, J. Chem. Phys., 58, 4766(1973).

12) C. Cossart-Magos, S. Leach, ibid., 64, 4006(1976).

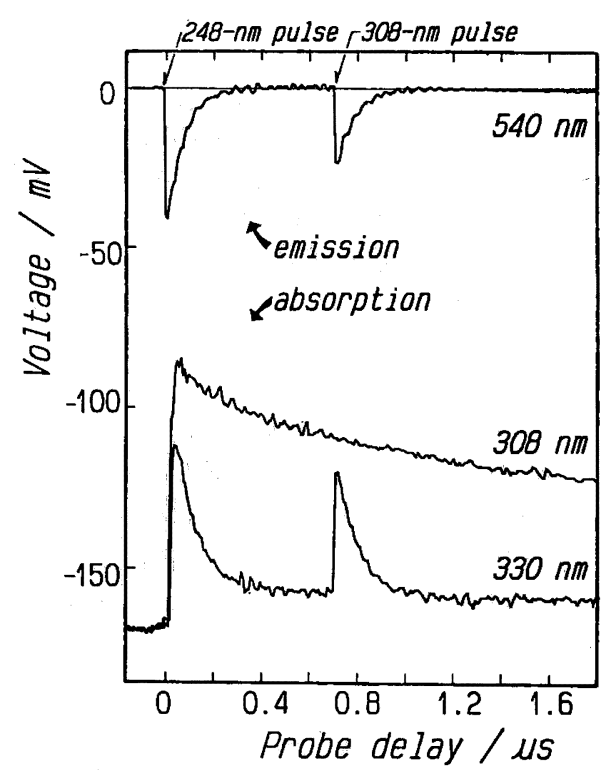

Fig. 3 Oscillogram traces for the two-step laserinduced-fluorescence (TS-LIF) and the twostep laser-induced-absorption (TS-LIA) of $p^{-}$ (chloromethyl)anisole $(2.9 \mathrm{mM}$ ) in hexane at room temperature

誘起するための時間は十分にある。脱気室温へキサン中の CMA を $\mathrm{KrF}$ レーザーパルス $(248 \mathrm{~nm})$ 励起して得られた過渡吸収の オッシログラムのらち，308 nm で観湘されたものを図 3 の中ほ どに示す。この波長は $p$-メトキシベンジルラジカル $\left(\mathrm{D}_{0}\right)$ の許容 $2 \mathrm{~A}_{2} \rightarrow 1 \mathrm{~B}_{2}$ 吸収帯にあり, $\mathrm{D}_{n} \leftarrow \mathrm{D}_{0}$ 励起のためのプローブレーザ 一である $\mathrm{XeCl}$ レーザーの発振波長である。図 3 上部のオッシ口 グラムは, $540 \mathrm{~nm}$ で観測したレーザー誘起蛍光のものである。 $248 \mathrm{~nm}$ パルス励起後, $308 \mathrm{~nm}$ レーザーで誘起された蛍光は 2 段 励起レーザー誘起蛍光 (Two-Step Laser-Induced-Fluorescen- 


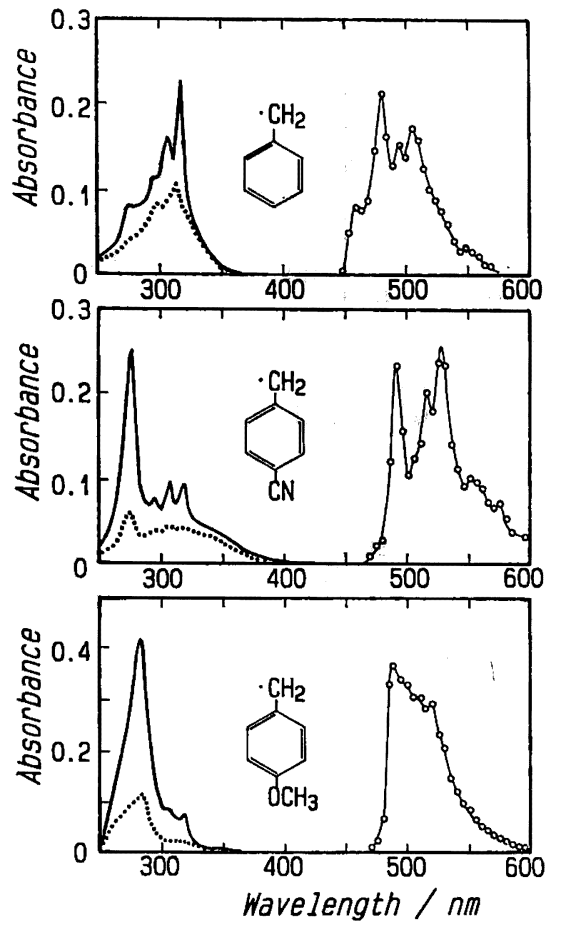

Fig. 4 Time-resolved absorption spectra and the two-step laser-induced-fluorescence (TSLIF) spectra of benzyl chloride, $\alpha$-bromo$p$-tolunitrile and $p$-(chloromethyl)anisole in hexane at room temperature

Solid spectra and dashed spectrum were observed at $1 \mu \mathrm{s}$ and $40 \mu \mathrm{s}$ delay from the $248 \mathrm{~nm} \mathrm{KrF} \mathrm{laser}$ photolysis

ce, TS-LIF) であり， $\mathrm{D}_{n} \leftarrow \mathrm{D}_{0}$ 励起に続く $\mathrm{D}_{n} \longrightarrow \mathrm{D}_{1}$ 電子緩和 により生成した $\mathrm{D}_{1}$ からの $\mathrm{D}_{1} \rightarrow \mathrm{D}_{0}$ 蛍光と考えられる。なお, $308 \mathrm{~nm}$ での CMA の分子吸光係数は非常に小さいので, $308 \mathrm{~nm}$ レーザーの単独励起ではラジカルの蛍光は検出されない。また, $120 \mathrm{~ns}$ の寿命を示すこの TS-LIF の強度は, $308 \mathrm{~nm}$ での基底状 態ラジカルの吸収の強度に比例するので, 二つのパルス間の遅延 時間が長いほど減少する。

$248 \mathrm{~nm}$ レーザーの単独励起では, $p$-メトキシベンジルラジカ ルの $\mathrm{D}_{1} \rightarrow \mathrm{D}_{0}$ 紗光が誘起された。これは $248 \mathrm{~nm}$ 光分解で速やか に生成したラジカル $\left(\mathrm{D}_{0}\right)$ が, むら 1 個の $248 \mathrm{~nm}$ 光を吸収して 励起されるためと考劣られ, 形式的には1段励起であるが本質的 には 2 段励起の現象である。なお，248nm パルスによる $\mathrm{D}_{n}$ $\mathrm{D}_{0}$ 励起では, $308 \mathrm{~nm}$ パルス励起よりさらに高い励起状態 $\left(\mathrm{D}_{n}\right)$ に励起された後, 緩和により萤光性状態 $\left(\mathrm{D}_{1}\right)$ が生成すると考文 られる。

一方, 420〜 460 nm の色素レーザーで微弱な $\mathrm{D}_{1} \leftarrow \mathrm{D}_{0}$ 吸収带を 励起して直接 $\mathrm{D}_{1}$ を生成させて, $120 \mathrm{~ns}$ の寿命の $\mathrm{D}_{1} \rightarrow \mathrm{D}_{0}$ 蛍光 を測定した。この TS-LIF 強度は, $2 \mathrm{~A}_{2}\left(\mathrm{D}_{n}\right) \leftarrow 1 \mathrm{~B}_{2}\left(\mathrm{D}_{0}\right)$ 吸収を $308 \mathrm{~nm}$ パルス励起した時の TS-LIF 強度にくらべはるかに小さ w。

図 4 の左側に室温へキサン中の塩化ベンジル， $\alpha$-ブロモ-p-ト ルニトリル, pークロロメチルアニソールの $248 \mathrm{~nm}$ パルス励起 $1 \mu \mathrm{s}$ 後および $40 \mu \mathrm{s}$ 後の過渡吸収スペクトルを示す。 $1 \mu \mathrm{s}$ 後の
スペクトルに見られる $\mathrm{D}_{n} \leftarrow \mathrm{D}_{0}$ 吸収のピークは二次の減衰を示 して $40 \mu \mathrm{s}$ 後のスペクトルにはわずかに認められ, 未同定の比較 的安定な生成物による幅広な吸収帯が残る。248 nm パルス励起 の $1 \mu \mathrm{s}$ 後に $308 \mathrm{~nm}$ パルス励起して得られたのが右側に示す TS-LIF 蛍光スペクトルで, これらはそれぞれベンジル; $p$-シア ノベンジル, $p$-メトキシベンジルラジカルの $\mathrm{D}_{1} \rightarrow \mathrm{D}_{0}$ 蛍光スペク トルと帰属される。室温へキサン中のペンジルの蓝光寿命は $1 \mathrm{~ns}$ 程度 ${ }^{23)}$ であるのに対し, パラ位に電子求引性基や電子供与性基を 導入した $p$-シアノベンジルや $p$-メトキシベンジルではそれぞれ $58,120 \mathrm{~ns}^{4)}$ と比較的長(蓝光寿命を示す。な拉, これらラジカ ルの蛍光スペクトルは, ベンジルの蛍光スペクトルにくらべて明 らかにレッドシフトしている。 トルのレッドシフトは, 吸収スペクトルのデータとよく一致して いる。すなわち, Claridge と Fischer によれば, 室温シクロへ キサン中の $p$-メトキシベンジルの可視吸収帯の 0,0 バンド波長 は $485 \mathrm{~nm}$ であり, ベンジルの 0,0 バンド波長の $463 \mathrm{~nm}$ にく

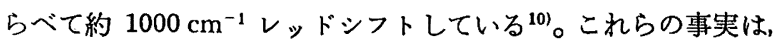
ベンジルラジカルのエネルギー準位などにおよぼすシアノ基やメ トキシ基の摄動が小さくないことを示唆している。

室温へキサン中の $p$-ハロゲノベンジルラジカルの $\mathrm{D}_{1} \rightarrow \mathrm{D}_{0}$ 蛍 光スペクトルも測定されたが, ヘンンジルや $p$-メチルベンジルの 蛍光スペクトルと同様の波長領域に現われ，格別のシフトは見ら れない。 $p$-フルオロベンジルおよび $p$-クロロベンジルの蛍光寿 命は比較的長く，それぞれ $200,81 \mathrm{~ns}$ と求まった。しかし，pブロモベンジルの蛍光寿命は $1 \mathrm{~ns}$ 以下と短い。

$3.1 .3 \mathbf{D}_{n} \leftarrow \mathbf{D}_{1}$ 吸収スペクトル：2段励起レーザー分光法に よる室温へキサン中のペンジルラジカルの $\mathrm{D}_{\mathrm{l}} \rightarrow \mathrm{D}_{0}$ 蛍光の測定に ついて述べてきたが，同様の分光法により蛍光発光状態 $\left(\mathrm{D}_{1}\right)$ の 過渡吸収の测定ができる。図 3 に $p$-クロロメチルアニソールの $540 \mathrm{~nm}$ TS-LIF シグナルを示したが, $330 \mathrm{~nm}$ で過渡吸収を測定 すると，第 2 段の $308 \mathrm{~nm}$ パルス励起により TS-LIF と同様の 減衰を示す新しい過渡吸収が检出された。この 2 段励起吸収 (TS-LIA) が， $p$-メトキシベンジルの $\mathrm{D}_{n} \leftarrow \mathrm{D}_{1}$ 吸収と考学られ る。

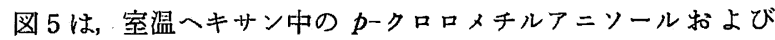
$\alpha$-プロモー $p$-トルニトリルを $248 \mathrm{~nm}$ パルスで光分解して, 基底 状態の $p$-メトキシベンジルおよび $p$-シアノベンジルを生成さ せ, その $400 \mathrm{~ns}$ 後に $308 \mathrm{~nm}$ パルスでベンジルラジカルを励起 して得られた TS-LIA スペクトルである。上因は $308 \mathrm{~nm} レ ー$ ザ一励起の $100 \mathrm{~ns}$ 後のスペクトルで, $300 \mathrm{~nm}$ より短波長領域の 負の吸収は，基底状態 $p$ メトキシベンジルの $4 \mathrm{~B}_{2} \leftarrow 1 \mathrm{~B}_{2}$ 吸収帯 のブリーチングであり, $340 \mathrm{~nm}$ 付近に極大を持つスペクトルは, 励起状態 $p$-メトキシベンジルの $\mathrm{D}_{n} \leftarrow \mathrm{D}_{1}$ 吸収と考えられる。一 方, 下図は, $308 \mathrm{~nm}$ レーザー励起の $43 \mathrm{~ns}$ 後のスペクトルで, $295 \mathrm{~nm}$ に極大を持つ正の吸収带は, 励起状態の $p$-シアノペンジ ルの $\mathrm{D}_{n} \leftarrow \mathrm{D}_{1}$ 吸収と㷌属できる。305 および $310 \mathrm{~nm}$ の測定点の 欠如は, $308 \mathrm{~nm}$ パルスの Rayleigh 散乱のためである。ここで注 目すべきは, 両ベンジルラジカルの $\mathrm{D}_{n} \leftarrow \mathrm{D}_{1}$ 吸収スペクトルがま ったく異なることである。特に, p-シアノベンジルの場合, 280 $\mathrm{nm}$ 付近に極大を有し，分子吸光係数が $32000 \mathrm{M}^{-1} \cdot \mathrm{cm}^{-113)}$ にも およぶ許容 $4 \mathrm{~B}_{2} \leftarrow 1 \mathrm{~B}_{2}\left(\mathrm{D}_{0}\right)$ 遷移のブリーチングを補儥しての正 の $\mathrm{D}_{n} \leftarrow \mathrm{D}_{1}$ 吸収の出現は鰵くべきであり，非常に許容な $\mathrm{D}_{n} \leftarrow$ 

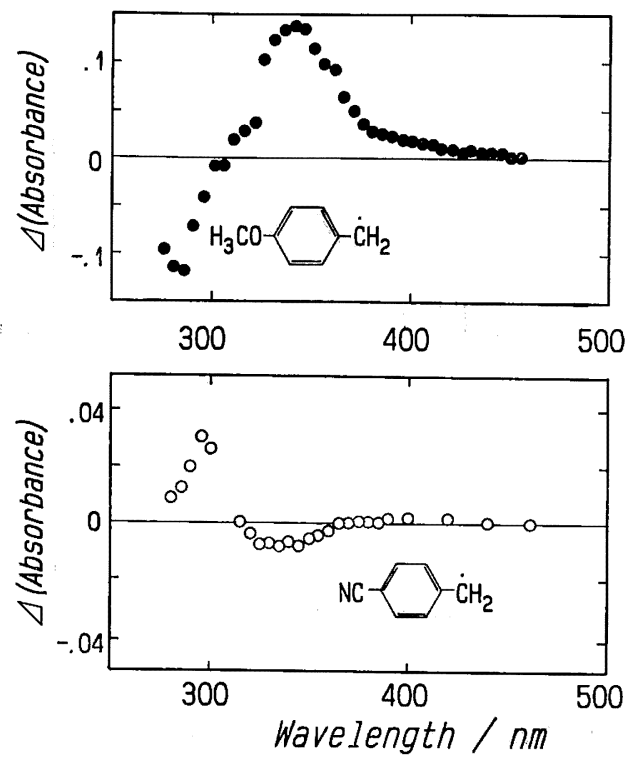

Fig. 5 Two-step laser-induced-absorption (TS-LIA) spectra of $p$-(chloromethyl)anisole and $\alpha$ bromo-p-tolunitrile in hexane at room temperature

\section{$\mathrm{D}_{1}$ 遷移が示唆される。}

\section{2 パラ置換ベンジルラジカルの蛍光消光}

幾つかのパラ䡩換ベンジルラジカルが, 室温へキサン中で比較 的長寿命の蛍光を発することが，確かめられた。これにより，励 起状態のヘンンジルラジカルの分子間相互作用や反応を, 鸴光消光 によって調べることができる。脂肪族ジアミンである DABCO は電子供与性である。DABCO とラジカルの前駆物質であるベン ジルハライドあるいは DABCO と基底状態ラジカルとの間の分 子間相互作用を示寸実験的証拠は何も得られなかった。しかし， $\mathrm{DABCO}$ によるパラ㯰換ベンジルラジカルの蛍光消光が効率よく 起こることが確かめられた。図 6,7 は典型的電子求引性基, 電子 供与性基を有する $p$-シアノベンジル， $p$-メトキシベンジルの蛍 光シグナルの減衰が $\mathrm{DABCO}$ 濃度增加により速くなることを示 している。Stern-Volmer プロットの傾きから p-シアノベンジル の蛍光消光速度定数は $2.6 \times 10^{10} \mathrm{M}^{-1} \cdot \mathrm{s}^{-1}$ と求まった。これは拡 散律速に近い值であり, $p$-メトキシベンジルの蛍光消光速度定数

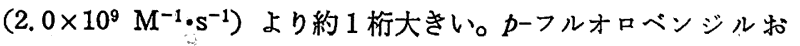
よび $p$-クロロベンジルの蛍光消光速度定数は $1.1 \times 10^{10}, 1.9 \times$ $10^{10} \mathrm{M}^{-1} \cdot \mathrm{s}^{-1}$ と求まった。

これに対して，これらラジカルの 1,4-シクロへキサジェン (CHD) による栄光消光に拈いて，いちじるしい置換基効果が確 かめられた。すなわち， pーメトキシベンジルの営光消光速度定数 $\left(9.4 \times 10^{5} \mathrm{M}^{-1} \cdot \mathrm{s}^{-1}\right)$ は非常に小さく, $p$-シアノベンジルの営光消 光速度定数 $\left(3.2 \times 10^{9} \mathrm{M}^{-1} \cdot \mathrm{s}^{-1}\right)$ の約 1/3500 に過ぎない。 $p->ル$

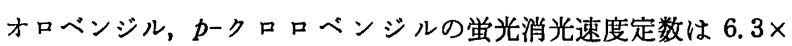
$10^{8}, 2.0 \times 10^{8} \mathrm{M}^{-1} \cdot \mathrm{s}^{-1}$ と見積られた。

\section{3 パラ置換ベンジルラジカルの蛍光増感}

先にパラ置換ベンジルラジカルの蛍光消光について述べたが,

13) P. Neta, D. Behar, J. Am. Chem. Soc., 103, 103 (1981).

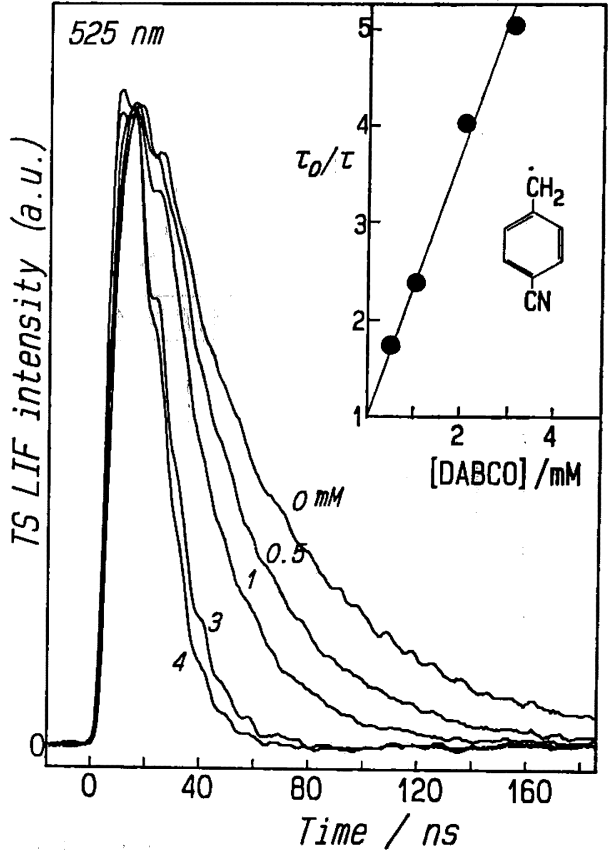

Fig. 6 Two-step laser-induced-fluorescence (TS-LIF) signals due to $p$-cyanobenzyl in the presence of various concentrations of $\mathrm{DABCO}$

Stern-Volmer plot is shown in the inset

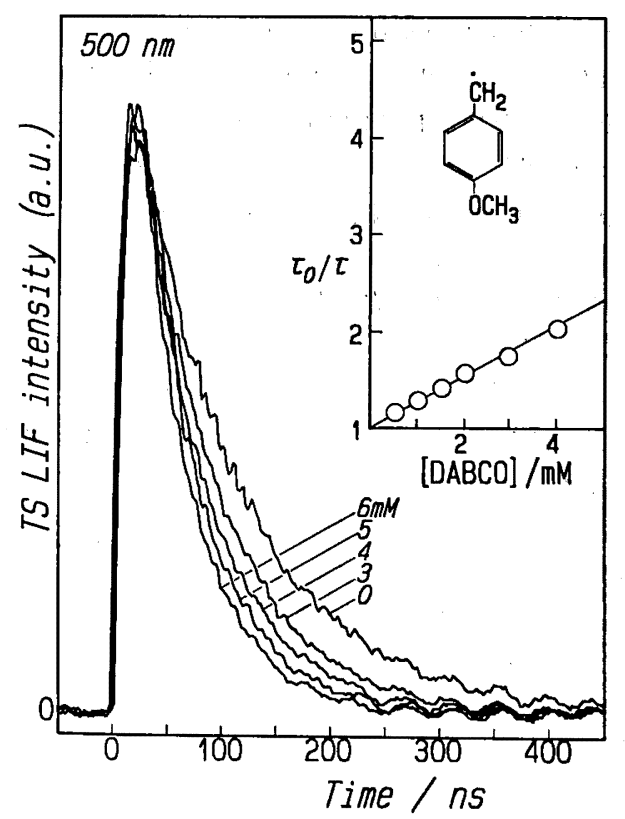

Fig. 7 Two-step laser-induced-fluorescence (TS-LIF) signals due to $p$-methoxybenzyl in the presence of various concentrations of DABCO

Stern-Volmer plot is shown in the inset

ここでは蛍光状態 $\left(D_{1}\right)$ の生成について述べる。四 8 に室温へキ サン中の塩化 $p$-クロロベンジル:(CBC) 扎よびpークロロトルエン (PCT) を $248 \mathrm{~nm}$ パルス励起し, 約 $1.3 \mu \mathrm{s}$ 後に $308 \mathrm{~nm}$ パル 


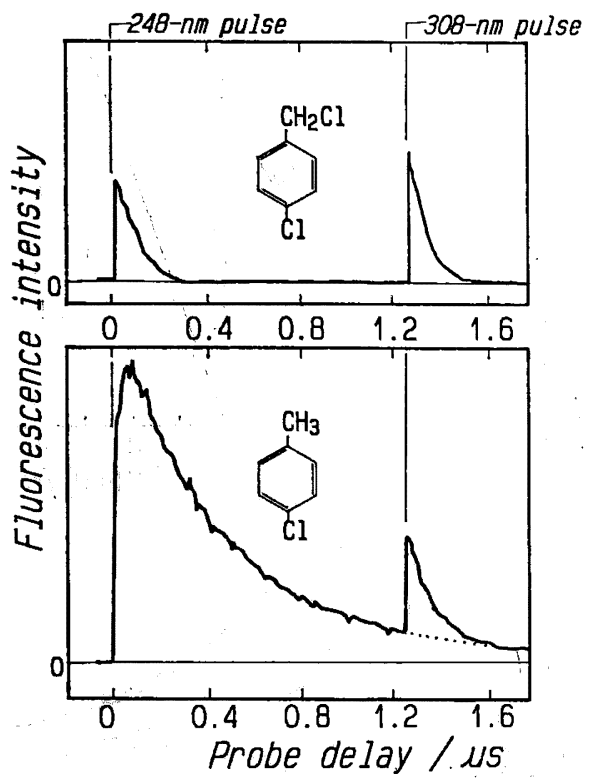

Fig. 8 LIF signals of $p$-chlorobenzyl chloride and $p$-chlorotoluene in hexane at room temperature

励起した時の LIF シグナルを示す。この四つの LIF のスペクト ルはすべて同一で, $p$-クロロベンジルラジカルの $\mathrm{D}_{1} \rightarrow \mathrm{D}_{0}$ 蛍光ス ペクトルである。一方，それらの寿命は $p$-クロロトルエンの $248 \mathrm{~nm}$ LIF が約 $700 \mathrm{~ns}$ と長いほかは，いずれす $81 \mathrm{~ns}$ であり， 室温へキサン中の $p$-クロロベンジルラジカルの蛍光寿命である。 $308 \mathrm{~nm}$ LIF は, 基底状態ラジカルのシンブルな励起による TSLIF である。これに対して $248 \mathrm{~nm}$ LIF はレーザー光分解の高密 度励起に因る現象と考兵られる。CBC の場合 $248 \mathrm{~nm}$ 光分解で生 成した $p$-クロロベンジル (基底状態) がも5 1 個の $248 \mathrm{~nm}$ 光に より励起される機構による TS-LIF である。これに対して,

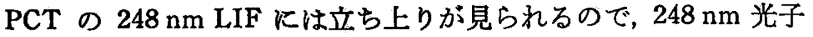
2 個による TS-LIF のほかに $p$-クロロベンジルの励起状態生成 に何らかの遅い過程を含んだ機構が示唆される。

図9に, PCT の $248 \mathrm{~nm} \mathrm{LIF}(500 \mathrm{~nm})$ と過渡吸収（317 $\mathrm{nm})$ を示すが，これらの減衰はほぼ対応している。スベクトルお゙ よび速度論的解析から，この過渡吸収の減衰は主として PCT の $\mathrm{T}_{n} \leftarrow \mathrm{T}_{1}$ 吸収の隇衰であり，これに $p$-クロロベンジルの $2 \mathrm{~A}_{2}$ $\leftarrow 1 \mathrm{~B}_{2}\left(\mathrm{D}_{0}\right)$ 吸収の二次減衰が重なっていると考えられる。

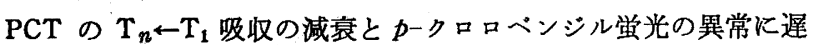
い減衰の対応は, PCT 三重項 $\left(\mathrm{T}_{1}\right)$ からラジカル二重項 $\left(\mathrm{D}_{0}\right)$

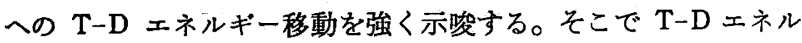
ギー移動により生成する励起状態ラジカル ( $\left.{ }^{2} \mathrm{R} \cdot *\right)$ の失活を逐次 反応（4）として捉光, ${ }^{2} \mathrm{R} ・ *$ の濃度を Runge-Kutta-Gill 法に より数值解析した。 T-D ネルギー移動が起こる時間領域での $\mathrm{R}$ ・の二次減衰が無視できるので，特別な補正を行っていない。

$$
{ }^{8} \mathrm{~T}^{*} \underset{\tau \mathrm{T}^{-1}}{\longrightarrow}{ }^{2} \mathrm{R} \cdot * \underset{\tau \mathrm{F}^{-1}}{\longrightarrow}{ }^{2} \mathrm{R} \text {. }
$$

この時, ${ }^{2} \mathrm{R} ・ *$ 濃度が最大になる時間 $\left(t_{\mathrm{max}}\right)$ は $(5)$ 式で表され る。

$$
t_{\max }=\left[\ln \left(\tau_{\mathrm{T}} / \tau_{\mathrm{F}}\right)\right] /\left(\tau_{\mathrm{F}}^{-1}-\tau_{\mathrm{T}}^{-1}\right)
$$

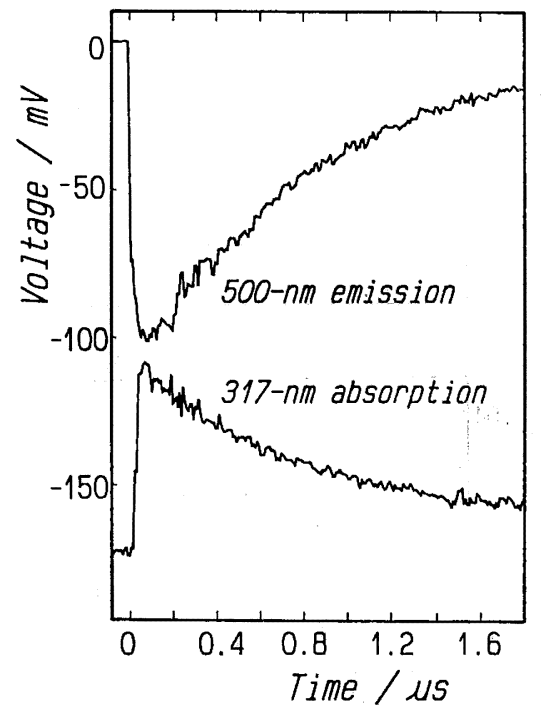

Fig. 9 Transient absorption $(317 \mathrm{~nm})$ and emission $(500 \mathrm{~nm})$ induced by the $248 \mathrm{~nm}$ laser pulse excitation of $p$-chlorotoluene in hexane at room temperature

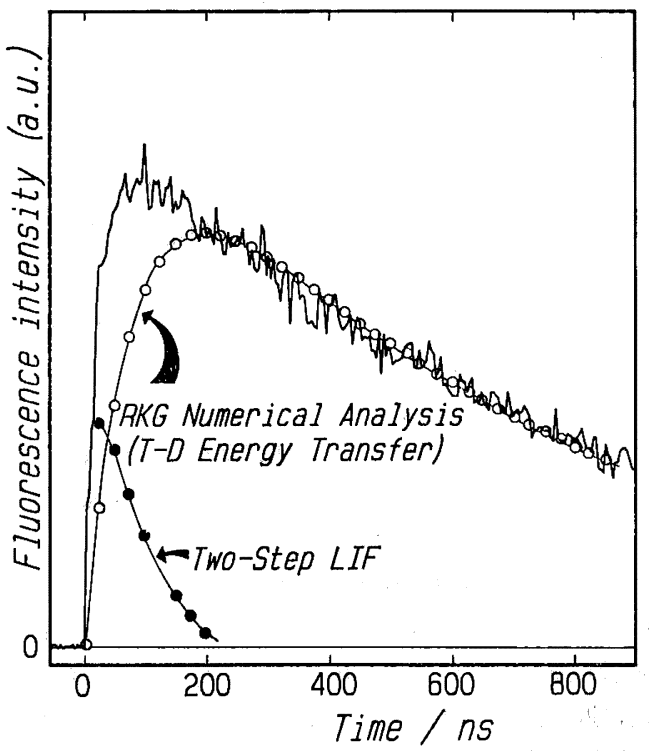

Fig. 10 The simulation of the $248 \mathrm{~nm}$ LIF of $p$-chlorotoluene by Runge-Kutta-Gill numerical analysis

過渡吸収減衰から得られた PCT 三重項のみかけの寿命 $\left(\tau_{\mathrm{T}}\right)$ が $710 \mathrm{~ns}$ であり， p-クロロベンジルの蛍光寿命が $81 \mathrm{~ns}$ であるの で, $t_{\max }$ は約 $200 \mathrm{~ns}$ である。図 10 に, レーザー強度が過渡吸 収測定と同一の時得られた実測の LIF シグナルと数值解析によ るシミュレーション曲線およびその差を示す。この差の減衰寿命 は約 $90 \mathrm{~ns}$ であることから, PCT の $248 \mathrm{~nm} \mathrm{LIF} \mathrm{は} 248 \mathrm{~nm}$ 光 子 2 個を段階的に吸収する TS-LIF と T-D エネルギー移動の二 つの機棈に基づく $p$-クロロベンジル蛍光であることがわかる。 CBC の $248 \mathrm{~nm}$ LIF に T-D エネルギー移動による蛍光がほと んど認められないのは, $248 \mathrm{~nm}$ パルス励起における 
ンジルの生成が支配的で, $\mathrm{CBC}$ 三重項濃度が低いためと考えら れる。

ところで，このような前駆物質三重項増感によるパラ直換ベン ジルラジカルの長寿命蛍光は, 多くのパラ直換トルエンの $248 \mathrm{~nm}$ レーザー光分解において検出された。室温へキサン中の $p$-ク口 ロトルエン, $p$-メチルアニソール, $p$-フルオロトルエンの 248 nm LIF および TS-LIF を図 11 に示す。

\section{4 結 論}

$\mathrm{C}_{2 \mathrm{v}}$ 対称性の偶交互芳香族炭化水素ラジカルであるベンジルラ ジカルの最低励起二重項 $\left(\mathrm{D}_{1}\right)$ と $\mathrm{D}_{2}$ の近接掞よび $1 \mathrm{~A}_{2}, 2 \mathrm{~B}_{2}$ への㷌属は, 理諭9141 18)や気相 ${ }^{121}$ あるいは低温マトリックス ${ }^{11)}$ 中 の分光データにより議論されて来た。本研究で得られた室温溶液 中のパラ置換ベンジルラジカルの励起状態についての知見は, こ の点について示唆に富む。すなわち，ベンジルのパラ位に典型的 電子求引性基あるいは電子供与性基を導入した $p$-シアノベンジ ルと $p$-メトキシベンジルでは, $\mathrm{D}_{n} \leftarrow \mathrm{D}_{1}$ 吸収スペクトルがまった く異なる。ところで, $\mathrm{D}_{n} \leftarrow \mathrm{D}_{1}$ 吸収スペクトルは，基底状態の $\mathrm{D}_{n} \leftarrow \mathrm{D}_{0}$ 吸収が大きい波長領域や $\mathrm{D}_{1} \rightarrow \mathrm{D}_{0}$ 蛍光スペクトルの波長 領域では測定できない。正の $\mathrm{D}_{n} \leftarrow \mathrm{D}_{1}$ 吸収が観測される場合でも $\mathrm{D}_{n} \leftarrow \mathrm{D}_{0}$ 吸収を初め, プローブレーザーで励起されるすべての （過渡）吸収のブリーチングによる補正が必要である。しかしな がらこれらの補正は非常に難しい。

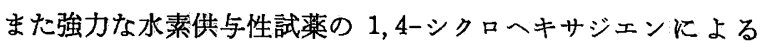
蛍光消光は, $p$-シアノベンジルの方が $p$-メトキシベンジルより はるかに起こりやすい。それゆ充，これら二つのベンジルでは $\mathrm{D}_{1}$ と $\mathrm{D}_{2}$ が逆転していると考えられる。最近平塚ら ${ }^{191201}$ は低温 PVA 膜中のパラ虍換トルェンの光分解により生成し，膜中に捕 捉された種々のパラ置換ベンジルラジカルについて蛍光の偏光度 を測定し，3-step photoselection の手法により営光性状態 $\left(D_{1}\right)$ の帰属を行った。その帰属が室温でも変わらないとすれば, $p-シ$ アノベンジル， p-メトキシベンジルの $\mathrm{D}_{1}$ はそれぞれ $2 \mathrm{~B}_{2}, 1 \mathrm{~A}_{2}$ と考えられる。

光分解パルス, プローブパルスとして $248,308 \mathrm{~nm}$ のエキシマ ーレーザーパルスを用いる 2 段励起レーザー分光法により室温溶 液中の励起状態ベンジルラジカルの電子スペクトルを測定した が，これにより拡散により起こる反応や分子間相互作用の研究が 可能となった。しかし，芳香族分子は $248,308 \mathrm{~nm}$ に比較的強い 吸収を有するために励起状態ラジカルの消光剤として使えない。 また，脂肪族分子でも $308 \mathrm{~nm}$ に吸収がないものを選ぶとなる

14) W. Bingel, Z. Naturforsch., 10 a, 462(1955).

15) Y.Mori, Bull. Chem. Soc. Jpn., 34, 1031, 1035 (1961).

16) P. Cársky, R. Zahradník, J. Phys. Chem., 74, 1249 (1970).

17) H. M. Chang, H. H. Jaffé, C. A. Masmanidis, ibid., 79, 1118(1975).

18) G. Orlandi, G. Poggi, F. Zerbetto, Chem. Phys. Lett., 115, 253(1985).

19）平塚浩士, 森 苝里, 閑 春夫, 福島 小尾欣一, 日 本化学会第 56 春季年会講演予稿集 I, p. 37 (1988).

20）平塚浩士, 横山敬士, 村形 哲, 森 临里, 閑 春夫, 福 島 勝, 小尾欣一, 分子構造総合討論会講演要旨集, p. 532 (1988).

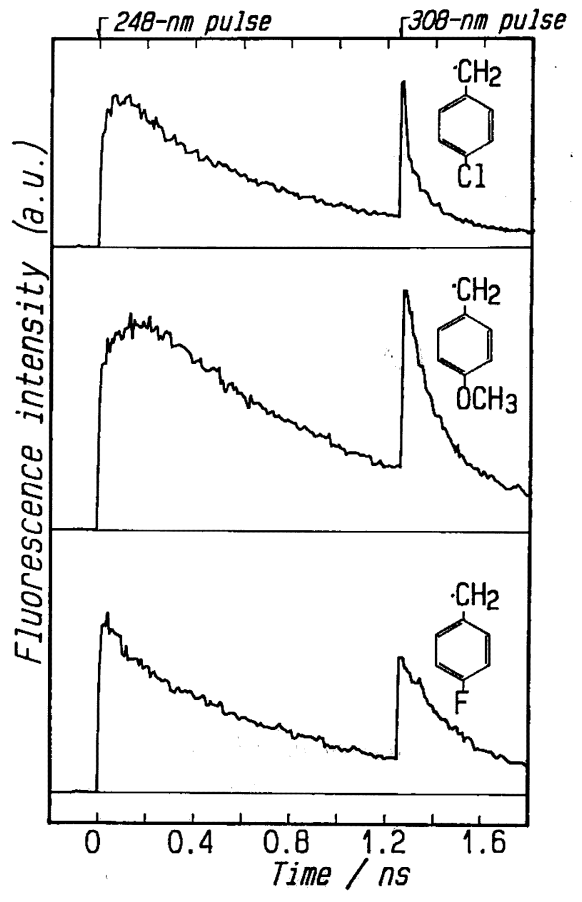

Fig. 11 LIF signals of $p$-chlorotoluene, $p$-methylanisole and $p$-fluorotoluene in hexane at room temperature

と，選択の範囲は非常にかぎられる。

$\mathrm{DABCO}$ や $\mathrm{CHD}$ による蛍光消光では土キシプレックス蛍光な どの新たな発光は観測されなかった。さらに, 二段励起吸収の測 定で DABCO カチオンラジカルの吸収が検出されなかったこと から, 励起状馝ヘンンシルと DABCO との間で電荷移動相互作用 による消光が起こり電子移動反応は起こっていないと考えられ る。一方，CHDによる消光の 2 段励起吸収の測定に打いては, 分子吸光係数 $\left(<100 \mathrm{M}^{-1} \cdot \mathrm{cm}^{-1} 500 \sim 600 \mathrm{~nm}\right)^{211}$ の小さいシク口 へキサジェニルラジカルの吸収は当然ながら検出されなかった。 しかしながら p-シアノベンジルラジカルについて, その $\mathrm{D}_{n} \leftarrow$ $\mathrm{D}_{0}$ 吸収のブリーチングが回復しないことが確かめられたので, 水素引拔き反応が起こっていると考えられる。

有機物三重項の常磁性分子による消光機構の一つと考えられる $\mathrm{T}-\mathrm{D}$ エネルギー移動は，みかけ上スピン保存則が成り立たない。 しかし, Razi Naqvi は, 三重項 $\left(\mathrm{T}_{1}\right)$ と二重項 $\left(\mathrm{D}_{0}\right)$ のェンカ ウンターにより電子交換相互作用が起こるために拡散律速に近い 速度で励起状態二重項 $\left(D_{1}\right)$ が生成する機構を示した ${ }^{22)}$ 。特にエ

21) J.C.Scaiano, M. Tanner, D. Weir, J. Am. Chem. Soc., 107, 4396(1985).

22) K. Razi Naqui, J. Phys. Chem., 85, 2303(1981).

23) K. Razi Naqvi, Urs P. Wild, Chem. Phys. Lett., 41, 570(1976).

24) K. Razi Naqvi, T. Gillbro, ibid., 49, 160(1977).

25) H. Hiratsuka, S. Rajadurai, P. K. Das, G. L. Hug, R. W. Fessenden, M. V. George, ibid., 137, 255(1987).

26) K. Bhattacharyya, P. K. Das, R.W. Fessenden, M. V. George, K. R. Gopidas, G. L. Hug, J. Phys. Chem., 89, 4164(1985). 
ネルギー受容体である二重項の蛍光の検出による T-D エネルギ 一移動の研究は, これまでベンゾフェノンケチル23) 25)やフラノ キシラジカル26) を用いて報告されているのみであり, ラジカル の流動性溶液中での蛍光能が強いことが必要である。

パラ置㓏トルェンの $248 \mathrm{~nm}$ パルス励起により競争的に生成し
た前駆物質（パラ置換トルエン）三重項から生成物（パラ直換ベ ンジルラジカル）への T-D エネルギー移動は自己増感といえ る。エネルギー受容体であるラジカルの $\mathrm{D}_{1} \rightarrow \mathrm{D}_{0}$ 蛍光が容易に検 出されたのは流動性溶媒中で高密度励起されたことに因るもの で，T-D エネルギー移動の何よりも確実な証明である。

\title{
Special Articles on
}

Structure and Reaction of Unstable Species

\author{
Electronic Spectra and Molecular Interaction of \\ para-Substituted Benzyl Radicals in the \\ Lowest Excited Doublet State \\ Kunihìro ToKumura* and Michiya IтоH
}

\begin{abstract}
Division of Life Sciences, Graduate School and Faculty of Pharmaceutical Sciences, Kanazawa University; Takara-machi, Kanazawa-shi 920 Japan
\end{abstract}

The room temperature $D_{1} \rightarrow D_{0}$ fluorescence spectra of various para-substituted benzyl radicals were induced by $248 \mathrm{~nm}$ laser photolysis of para-substituted benzyl halides followed by $308 \mathrm{~nm}$ laser pulse excitation. The fluorescence lifetimes of $p$-cyanobenzyl, $p$-fluorobenzyl, $p$ chlorobenzyl and $p$-methoxybenzyl in hexane at room temperature were determined to be 58, 200, 81 and $120 \mathrm{ns,}$ respectively. Such relatively long fluorescence lifetimes enabled us to examine the fluorescence quenching by electron-donating diazabicyclo[2.2.2] octane and $\mathrm{H}$-donating 1,4-cyclohexadiene (CHD). The fluorescence quenching by CHD was found to exhibit a pronounced substituent effect. The quenching rate constant $\left(3.2 \times 10^{9} \mathrm{M}^{-1} \cdot \mathrm{s}^{-1}\right)$ of the $p$-cyanobenzyl fluorescence was about three orders of magnitude larger than that $\left(9.4 \times 10^{5} \mathrm{M}^{-1} \cdot \mathrm{s}^{-1}\right)$ of $p$-methoxybenzyl fluorescence. Completely different $\mathrm{D}_{n} \leftarrow \mathrm{D}_{1}$ absorption spectra $\left(\lambda_{\max }=295 \mathrm{~nm}\right.$ and $340 \mathrm{~nm}$ for $p$-cyanobenzyl and $p$-methoxybenzyl) were obtained as shown in Fig. 5. These results strongly indicate the different assignment $\left(1 A_{2}\right.$ or $2 \mathrm{~B}_{2}$ ) to the lowest excited doublet state of $p$-cyanobenzyl and $p$-methoxybenzyl.

On the other hand in the $248 \mathrm{~nm}$ laser photolysis of $p$-chlorotoluene in hexane at room temperature, the triplet-doublet electronic energy transfer from $p$-chlorotoluene to $p$-chlorobenzyl radical was clearly confirmed by the detection of the long-lived $D_{1} \rightarrow D_{0}$ fluorescence due to the presence of $p$-chlorobenzyl (energy acceptor). 